\title{
Percentages of CD4+CD8+ Double-positive T Lymphocytes in the Peripheral Blood of Adults from a Blood Bank in Bogotá, Colombia
}

\author{
Kolombiya Bogota Kan Bankası Yetişkin Periferik Kan CD4+CD8 + Çift Pozitif T-Lenfosit \\ Yüzdeleri
}

(D) Miguel S. Gonzalez-Mancera1, (D) Natalia I. Bolaños¹, (D) Manuel Salamanca1†, (D) Guillermo A. Orjuela², (D) Ayda N. Rodriguez², (D) John M. Gonzalez ${ }^{1}$

1 University of los Andes, School of Medicine, Grupo de Ciencias Básicas Médicas, Bogotá, Colombia

${ }^{2}$ National Blood Bank, Colombian Red Cross, Bogotá, Colombia

\section{Abstract}

Objective: $C D 4+C D 8+$ double-positive T-cells (DPTs) have been classified as a separate T-cell subpopulation, with two main phenotypes: $C D 4^{\text {high }} \mathrm{CD} 8^{\text {low }}$ and $\mathrm{CD} 4$ low $\mathrm{CD} 8^{\text {high. In }}$ recent years, the relevance of DPTs in the pathogenesis of infections, tumors, and autoimmune diseases has been recognized. Reference values among healthy individuals remain unknown. Therefore, the aim of this study is to provide a reference value for DPTs in peripheral blood from healthy donors in a blood bank in Bogotá, Colombia, and to determine the activation status using a surface marker.

Materials and Methods: One hundred healthy donors were enrolled in the study. Peripheral blood cells were stained for CD3, CD4, CD8, and CD154 (CD40L), and cellular viability was assessed with 7-aminoactinomycin $\mathrm{D}$ and analyzed by flow cytometry.

Results: The median value for DPTs was 2.6\% (interquartile range $=1.70 \%-3.67 \%)$. Women had higher percentages of DPTs than men (3.3\% vs. $2.1 \%$ ). The subpopulation of CD4low CD8high showed higher expression of CD154 than the other T-cell subpopulations.

Conclusion: DPT reference values were obtained from blood bank donors. A sex difference was found, and the CD4low CD8high subpopulation had the highest activation marker expression.

Keywords: Flow cytometry, Lymphocyte, Lymphocyte subpopulation, T lymphocytes

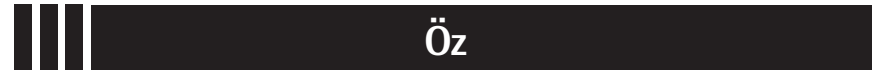

Amaç: $C D 4+C D 8+$ çift pozitif T hücreleri (ÇPT) ayrı bir T hücre alt popülasyonu olarak iki temel fenotip ile sınıflandırılmaktadır: CD4yüksek CD8düşük ve CD4düşük CD8yüksek. Son yıllarda, ÇPT'lerin enfeksiyonlar, tümörler ve otoimmün hastalıkların patogenezi ile ilişkisi tanımlanmıştır. Sağlıklı bireyler arasında referans değerleri bilinmemektedir. Bu nedenle, bu çalışmanın amacı, Kolombiya Bogota'daki bir kan bankasındaki sağlıklı vericilerden alınan periferik kandaki ÇPT'ler için bir referans değeri sağlamak ve bir yüzey belirteci kullanarak aktivasyon durumunu belirlemektir.

Gereç ve Yöntemler: Çalışmaya yüz sağlıklı verici dahil edilmiştir. Periferik kan hücreleri CD3, CD4, CD8 ve CD154 (CD40L) için işaretlendi ve hücresel canlılık 7-aminoactinomycin D kullanarak akan hücre ölçer ile analiz edildi.

Bulgular: ÇPT'ler için ortanca değer \%2,6 (çeyrekler arası aralık=\%1,70-\%3,67) olarak saptandı. Kadınlarda ÇPT yüzdesi erkeklere göre daha yüksek bulundu $(\% 3,3$ karşı $\% 2,1)$. CD4düşük CD8yüksek alt popülasyonu diğer T hücre alt popülasyonlarından daha yüksek CD154 ekspresyonu gösterdi.

Sonuç: ÇPT referans değerleri kan bankası vericilerinden elde edilmiştir. Cinsiyetler arası fark ve CD4düşük CD8yüksek alt popülasyonunda da en yüksek aktivasyon belirteci ekspresyonu saptanmıştır.

Anahtar Sözcükler: Hücre ölçer, Lenfosit, Lenfosit alt popülasyonu, T lenfositleri

\section{Introduction}

Classically, T-cells have been classified according to the cell surface markers CD4 and CD8. The expression of these proteins is considered to be a mutually exclusive event reflecting the specific functions of each major T-cell population in peripheral blood: CD4+ or helper T-cells and CD8+ or cytotoxic T-cells.
However, with the use of multiparametric cellular analysis methods, a variety of minor T-cell subpopulations have been described [1], such as mature CD4+CD8+ or double-positive T-cells (DPTs) [2,3]. This T-cell phenotype was initially described in the thymus, where more than $80 \%$ of thymocytes expressed both $\mathrm{CD} 4+\mathrm{CD} 8+$, which later commit to one cell lineage (CD8+ 
or CD4+) after interaction with human leukocyte antigen (HLA) class I or II molecules, respectively [4]. The origin of DPTs in the peripheral blood of healthy individuals has been attributed to the premature release of CD4+CD8+ T-cells from the thymus to the periphery $[5,6,7]$. However, additional studies have suggested that DPTs could originate from the acquisition of the second marker by single-positive (either CD4+ or CD8+) T-cells in the periphery $[6,8]$. Although several investigations support that mature CD4+ T-cells are the source of DPTs, there is also evidence that CD8+ T-cells could be the primary cellular type [6]. Unlike immature thymic DPTs, peripheral DPTs exhibit the functional properties of mature T-cells, including antigendependent cytokine production, cytolytic activity, and expression of markers associated with the memory phenotype $[9,10]$. DPTs are divided into two main populations based on the differential expression of each marker (CD $4^{\text {high }} \mathrm{CD} 8^{\text {low }}$ and $\left.\mathrm{CD} 4^{\text {low }} \mathrm{CD} 8^{\text {high }}\right)$ $[1,2,3]$. In healthy donors, $C D 4^{\text {high }} C D 8^{\text {low }}$ cells have an effector or memory phenotype $\left(\mathrm{T}_{E \mathrm{M}}\right)$, whereas $C D 4^{\text {low }} \mathrm{CD} 8^{\text {high }}$ cells display a central memory phenotype $\left(T_{C M}\right)$, which can switch to an effector phenotype during viral infections such as hepatitis $\mathrm{C}$ virus (HCV) and human immunodeficiency virus (HIV) $[9,10]$. Little is known about the functionality of DPTs, though their function seems to be disease-specific. DPTs exhibit cytotoxic potential in chronic viral infections, such as lymphocytic choriomeningitis virus [11] and HIV [12], and in certain types of cancer $[13,14,15]$. DPTs can have a regulatory role in malignancies $[13,14]$, systemic sclerosis [16], and inflammatory bowel disease [17]. In autoimmune diseases, DPTs can be found in different compartments; they increase in peripheral blood among patients with myasthenia gravis [18] but are found infiltrating the affected tissues in autoimmune thyroid disease and rheumatoid arthritis $[19,20]$. In systemic sclerosis and rheumatoid arthritis, DPTs secrete mainly interleukin-4 $[16,19]$, whereas in tumors, such as melanoma and cutaneous lymphoma, the primary cytokine produced is tumor necrosis factor (TNF)- $\alpha[13,14]$. In chronic parasitic infections such as Chagas disease, DPTs are not only increased in peripheral blood [21] but are also found infiltrating the cardiac tissue in patients with advanced chagasic cardiomyopathy $[22,23]$.

Due to the growing interest in the study of DPT subpopulations and their potential roles in specific diseases, it seems essential to determine reference values among healthy individuals. Therefore, the main goal of this study is to establish standard values of DPTs and to evaluate their functional profile by determining the presence of one specific activation marker in suitable donors from a blood bank in Bogotá, Colombia.

\section{Materials and Methods}

\section{Study and Donors}

This is a descriptive and cross-sectional study of suitable donors who volunteered for blood donation in 2017 at the National
Blood Bank of the Colombian Red Cross in Bogotá, Colombia. The protocol and informed consent was approved by the Ethical Committee of the University of los Andes (Act 209 of 2013). One hundred and three donors were enrolled in this study and provided informed consent. The demographic characteristics of our study population are shown in Table 1. Three individuals were excluded due to reactive serological tests for syphilis. The study population included 55 men and 45 women who fulfilled the donation requirements and had negative screening tests (HIV, syphilis, hepatitis C virus, hepatitis B virus, Chagas disease, and human T-cell lymphotropic virus). They ranged from 19 to 61 years of age. Samples were obtained from citrate phosphate dextrose anticoagulated blood bags and transported refrigerated from the blood bank to the biomedical sciences laboratory where the cellular analyses were conducted.

\section{Cell Labeling and Cytometry Acquisition}

Blood samples of $100 \mu \mathrm{L}$ were used for labeling. Antibodies included anti-CD3 APC (clone UCHT1), anti-CD4 PerCP (SK3), anti-CD8 FITC (SK1), and anti-CD154 PE (TRAP1). All antibodies were purchased from BD Pharmingen (BD, San Diego, CA, USA). Blood was stained in darkness for $30 \mathrm{~min}$ at $4^{\circ} \mathrm{C}$ and then incubated with a cell lysis buffer (BD FACS Lysing Solution) for $15 \mathrm{~min}$ at room temperature. Subsequently, cells were washed twice in phosphate-buffered saline (PBS) (SigmaAldrich, St. Louis, MO, USA) (0.01 M, pH 7.4, PBS 1X) and gently resuspended. Viability was assessed with 7-aminoactinomycin $D$ staining (7-AAD, BD). Samples were acquired and analyzed with a FACSCanto II flow cytometer with FACSDiva 6.1 software (BD Bioscience, San Jose, CA, USA). At least $5 \times 10^{4}$ cells were acquired in the CD3+ T lymphocyte population gate according to their forward scatter (FSC) and side scatter (SSC) features. The gating strategy for CD3+ T-cells and DPTs is shown in Figure 1.

\section{Statistical Analysis}

Information about the donor characteristics is given in percentages. The Shapiro-Wilk normality test was conducted for all data obtained from the cellular analysis. A nonparametric statistical analysis was performed in the study. The MannWhitney $\mathrm{U}$ test was used to compare between two groups. The Kruskal-Wallis test was used to compare among multiple groups. The results are shown as medians and interquartile ranges

Table 1. Characteristics of the population studied.

\begin{tabular}{|l|l|l|l|l|}
\hline \multicolumn{5}{|l|}{ Age groups } \\
\hline Ages & $\mathbf{1 8 - 2 9}$ & $\mathbf{3 0 - 4 9}$ & $\mathbf{5 0 - 6 5}$ & Total \\
\hline Women & 11 & 18 & 16 & 45 \\
\hline Men & 6 & 33 & 16 & 55 \\
\hline No. & 17 & 51 & 32 & 100 \\
\hline Age average ( \pm SD) & $24.4(3.5)$ & $40.9(6.4)$ & $55.7(3.0)$ & $42.9(11.8)$ \\
\hline Age in years, SD: Standard deviation. \\
\hline
\end{tabular}


(IQRs). Statistical analysis was performed using GraphPad Prism 7 software (San Diego, CA, USA). Significance was established at $p<0.05$.

\section{Results}

T lymphocytes are a highly heterogeneous group of immune cells that have been of great interest in clinical and biomedical research studies. In an effort to establish values between the different subpopulations of DPTs, lymphocytes were analyzed from peripheral blood mononuclear cells from each blood donor included in the study. Lymphocytes were gated according to FSC vs. SSC features, as shown in Figure 1A. The median cell viability was $99.15 \%(I Q R=98.8 \%-99.4 \%)$ in all samples, as shown in Figure 1B. CD3+ T-cells were subsequently identified according to cell surface expression of CD4 or CD8, as shown in Figures $1 \mathrm{C}$ and $1 \mathrm{D}$, respectively. DPTs were classified into two main subpopulations, $C D 4^{\text {high }} \mathrm{CD} 8^{\text {low }}$ and $\mathrm{CD} 4^{\text {low }} \mathrm{CD} 8^{\text {high }}$, as shown in Figure 1D. The median total percentage of DPTs among CD3+ T-cells in all samples studied was $2.6 \%(\mathrm{IQR}=1.7 \%-3.67 \%)$, and the $C D 4^{\text {high }} \mathrm{CD} 8^{\text {low }}$ subpopulation showed a median content of $1.15 \%(I Q R=0.8 \%-2.0 \%)$, whereas in the $C D 4^{\text {low }} C D 8^{\text {high }}$ subpopulation, it was $0.9 \%(\mathrm{IOR}=0.5 \%-1.67 \%)$, as shown in Figure $2 \mathrm{~A}$. CD4 ${ }^{\text {high }} \mathrm{CD} 8^{\text {low }}$ accounted for $57.97 \%$ of DPTs, as shown in Figure 2B. Total DPTs were analyzed according to sex. Women showed a higher percentage of DPTs (median $=3.3 \%$; $\mathrm{IQR}=2.2 \%-4.15 \%$ ) than men (median $=2.1 \%$; IQR $=1.6 \%-3.3 \%$ ), $p=0.007$, as shown in Figure 3 . The activation status of DPTs was assessed by using the surface marker expression of CD154, also called $\mathrm{CD} 40 \mathrm{~L}$, as shown in Figure $1 \mathrm{E}$. The subpopulation of $C D 4^{\text {low }} C D 8^{\text {high }}$ showed higher expression of CD154 than the other T-cell populations $(p \leq 0.0001)$, as shown in Figure 4.

\section{Discussion}

In recent decades, there has been growing interest in CD4+CD8+ double-positive T lymphocytes, which are considered a separate subpopulation of T-cells associated with different pathologic conditions. In this study, a reference percentage value was established among DPT subpopulations. An activation marker was also studied in the blood samples of volunteer blood bank donors. An increased frequency of DPTs was found in women compared to men. Sex variance has been found in other blood cell subpopulations, such as natural killer lymphocytes $[24,25]$, and it would be of particular interest to evaluate DPTs during pregnancy and in placental tissue due to the sex difference found.

The frequency of DPTs in peripheral blood does not increase in HIV, HCV, or melanoma; however, this subpopulation exhibited a higher expression of surface activation markers (i.e. HLA-DR and CD38) and greater cytokine production (i.e. interferon- $\gamma$ and TNF- $\alpha$ ) in individuals with these diseases when compared to controls $[7,9,10,14]$. Nonetheless, in one study assessing HIV, an increased frequency of DPTs expressing CD38 and HLA-DR was associated with advanced disease in patients with CD4+ counts

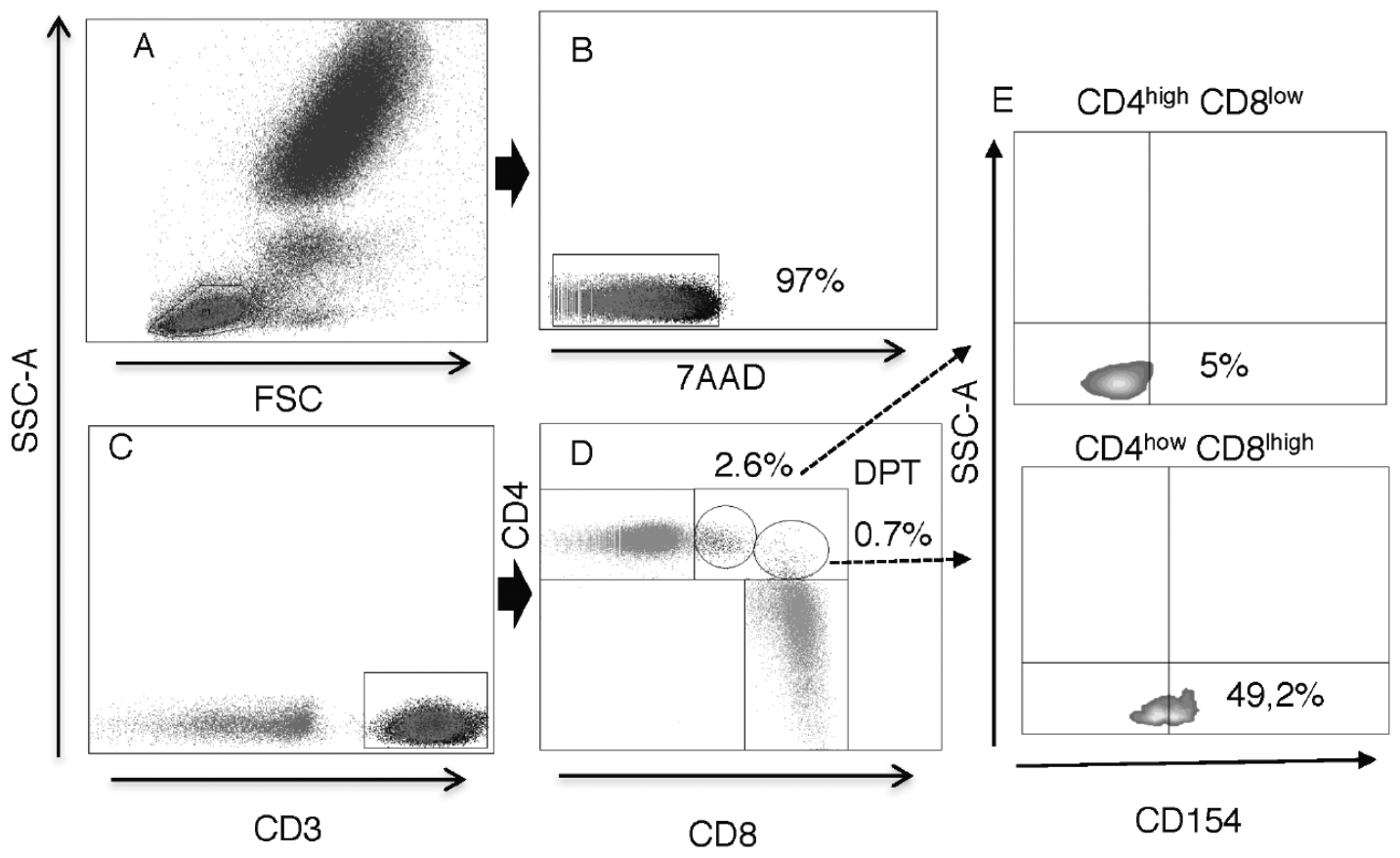

Figure 1. Flow cytometry gating strategy. A) Peripheral blood leukocytes cells distributed in dot plot by flow cytometry according to FSC versus SSC. B) Cell viability using 7-aminoactinomycin D. C) T-cells identified by the expression of CD3. D) Dot plot distribution showing the expression of CD4 and CD8, and the gate on DPTs: CD4high CD8low and CD4low CD8high. E) Density plot showing CD154 expression in each DPT subpopulation.

SSC: Side scatter, FSC: Forward scatter, DPTs: Double-positive T-cells, DPT: Double-positive T-cell. 

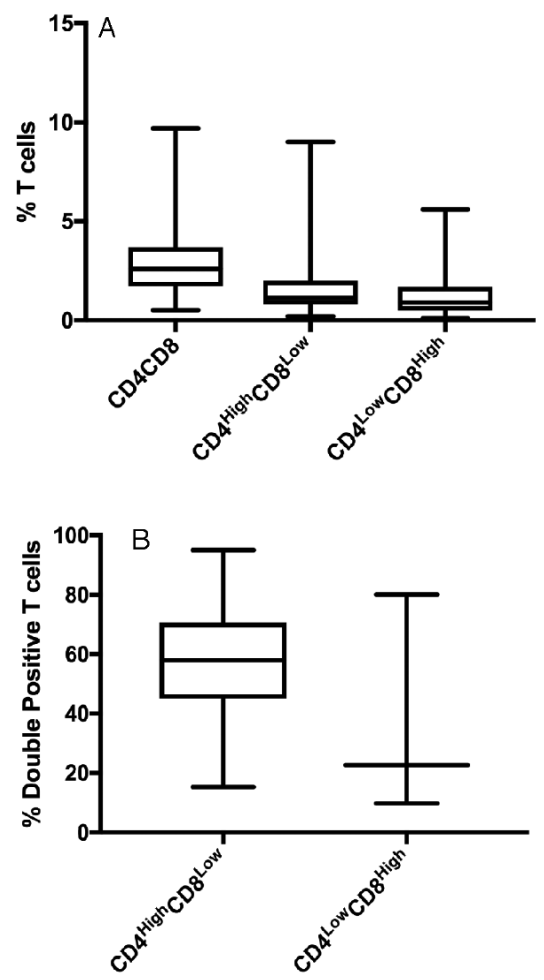

Figure 2. A) Percentage of subpopulations of DPTs from the total T lymphocytes. B) Percentage of subpopulations among the total DPTs. Data are displayed as medians with minimums and maximums.

DPTs: Double-positive T-cells.

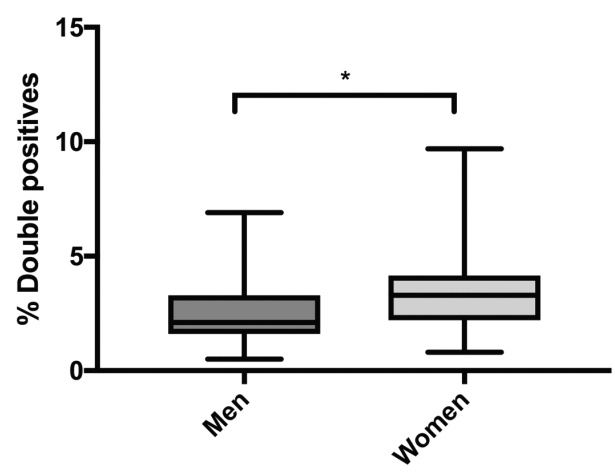

Figure 3. Percentage of the total DPTs according to sex. Women had higher percentages of DPT cells than men. Mann-Whitney, $\mathrm{p}=0.007$. Data are displayed as medians with minimums and maximums.

DPT: Double-positive T-cell.

of $<200$ cells $/ \mu \mathrm{L}$ [7], which are markers that have been widely used to define T-cell activation by antigens [26]. Additionally, an increased frequency of DPTs in peripheral blood was found in chronic chagasic patients [22,23] and among individuals with myasthenia gravis [18], and the percentage of DPTs interestingly decreased after treatment in both diseases [18,23]. Among

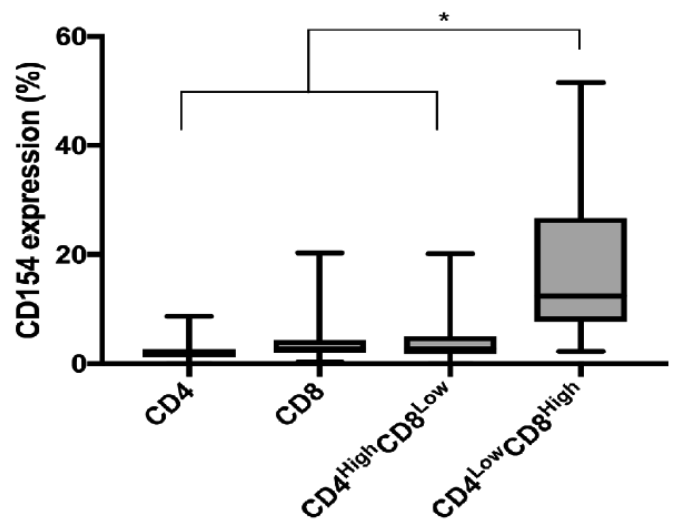

Figure 4. Expression of CD154 in single-positive and doublepositive T-cell subpopulations. The subpopulation CD4low CD8high had higher CD154 expression than other subpopulations of T-cells. Data are displayed as medians with minimums and maximums.

patients with melanoma, there was an increased frequency of DPTs in draining lymphoid nodes and tumor-infiltrating lymphocytes [14].

In this study, a higher expression of CD154 (CD40L) was found in $\mathrm{CD} 4^{\text {low }} \mathrm{CD} 8^{\text {high }}$ cells. This activation marker has been used as an indicator for antigen-specific T-cell activation in CD4+ T-cells [27] and in CD8+ T-cells [28]. Remarkably, this DPT subpopulation has an effector memory phenotype $[9,10]$. CD154 is the ligand of CD40, and this axis has been found to be of particular interest in the therapy of autoimmune diseases [29]. It would be very important to elucidate the functional role of CD154 in DPTs. Other markers have been studied on DPT cells, including activation, homing, and differentiation markers $[10,22]$. Due to the role of DPTs in the pathogenesis of several diseases, it seems promising to study the expression of inhibitory molecules such as PD-1 or CTLA-4. These molecules are currently targets of immunotherapy for different tumor conditions $[30,31,32]$. In previous reports, no other activation markers, such as CD38 or HLA-DR, were found in DPTs from healthy donors $[7,10,22]$.

In this study, a median DPT rate of 2.6\% was found, which was a higher result than that of the control donors in previous studies. For instance, in controls used to study DPTs in HIV patients, the median was $0.8 \%$ (IOR=0.1\%-1.2\%) [7]; in melanoma, the mean was $0.9 \%$ [standard deviation (SD) \pm 0.6 ] [14]; in HCV infection, the mean was $1 \%(S D \pm 0.6)$ [10]; and in chronic Chagas disease, the mean was $1.1 \%( \pm 0.5)$ [22]. However, the control donors analyzed in these studies were from small cohorts, and demographic information about blood donor characteristics was lacking. Our study sample was significantly larger than those included in prior investigations, which could explain the increments evidenced in the results. Indeed, in one study, the frequency of DPTs ranged from $0 \%$ to $5 \%$ in control donors [18]. 


\section{Conclusion}

These findings and the differences found between the sexes can be used for future reference in specific populations and diseases. The limitations of this study include the age restriction of our sample and the limited screening tests performed for each donor. To the best of our knowledge, this is the first study to assess the frequency of DPTs in a large cohort of blood bank donors.

\section{Acknowledgments}

We would like to thank all the donors who volunteered to be a part of this study; the personnel of the National Blood Bank of the Colombian Red Cross who aided in the collection of the samples; and Juan Guillermo Ripoll, M.D., of the Mayo Clinic for revising the manuscript. This project was performed and finalized in memory of Manuel Salamanca, who conceived, wrote, and standardized the protocols.

\section{Ethics}

Ethics Committee Approval: The protocol and informed consent was approved by the Ethical Committee of the University of los Andes (Act 209 of 2013).

Informed Consent: Blood sample acquisition, obtaining of informed consent.

\section{Authorship Contributions}

Concept: G.A.O., A.N.R.; Design: M.S.; Data Collection or Processing: M.S.G.M., N.I.B., J.M.G.; Analysis or Interpretation: M.S.G.M., N.I.B., J.M.G.; Writing: M.S.G.M., N.I.B., J.M.G.

Conflict of Interest: The authors declare that they have no conflict of interest.

Financial Disclosure: The authors declare that this study received no financial support.

\section{References}

1. Zloza A, Al-Harthi L. Multiple populations of $\mathrm{T}$ lymphocytes are distinguished by the level of CD4 and CD8 coexpression and require individual consideration. J Leukoc Biol 2006;79:10-12.

2. Blue ML, Daley JF, Levine H, Schlossman SF. Coexpression of T4 and T8 on peripheral blood T cells demonstrated by two-color fluorescence flow cytometry. J Immunol 1985;134:2281-2286.

3. Ortolani C, Forti E, Radin E, Cibin R, Cossarizza A. Cytofluorimetric identification of two populations of double positive (CD4+,CD8+) T lymphocytes in human peripheral blood. Biochem Biophys Res Commun 1993;191:601-609.

4. Germain RN. T-cell development and the CD4- CD8 lineage decision. Nat Rev Immunol 2002;2:309-322.

5. de Meis J, Aurélio Farias-de-Oliveira D, Nunes Panzenhagen PH, Maran $N$, Villa-Verde DM, Morrot A, Savino W. Thymus atrophy and doublepositive escape are common features in infectious diseases. J Parasitol Res 2012;2012:574020.
6. Overgaard NH, Jung J-W, Steptoe RJ, Wells JW. CD4+/CD8+ doublepositive T cells: more than just a developmental stage? J Leukoc Biol 2015;97:31-38.

7. Chauhan NK, Vajpayee M, Mojumdar K, Singh R, Singh A. Study of CD4+CD8+ Double Positive T-Lymphocyte Phenotype and Function in Indian Patients Infected With HIV-1 Neeraj. J Med Virol 2012;84:845856.

8. Sullivan $Y B$, Landay $A L$, Zack JA, Kitchen $S G$, Al-Harthi L. Upregulation of CD4 on CD8+ T cells: CD4dimCD8bright $T$ cells constitute an activated phenotype of CD8+ T cells. Immunology 2001;103:270-280.

9. Howe R, Dillon S, Rogers L, Palmer B, MaWhinney S, Blyveis N, Schlichtemeier $R$, D'Souza M, Ingoldby L, Harwood JE, Rietmeijer C, Ray G, Connick E, Wilson CC. Phenotypic and functional characterization of HIV-1-specific CD4+ CD8+ double-positive T cells in early and chronic HIV-1 infection. J Acquir Immune Defic Syndr 2009;50:444-456.

10. Nascimbeni $M$, Shin $E$, Chiriboga L, Kleiner DE, Rehermann B. Peripheral CD4+ CD8+ T cells are differentiated effector memory cells with antiviral functions. Blood 2004;104:478-486.

11. Kitchen SG, Whitmire JK, Jones NR, Galic Z, Kitchen CMR, Ahmed R, Zack JA. The CD4 molecule on CD8+ T lymphocytes directly enhances the immune response to viral and cellular antigens. Proc Natl Acad Sci U S A 2005; 102:3794-3799.

12. Kitchen SG, Jones NR, LaForge $S$, Whitmire JK, Vu BA, Galic Z, Brooks DG, Brown SJ, Kitchen CM, Zack JA. CD4 on CD8+ T cells directly enhances effector function and is a target for HIV infection. Proc Natl Acad Sci U S A 2004;101:8727-8732.

13. Charue D, Bernheim A, Chouaib S, Boumsell L, Bensussan A. Isolation of tumor-specific cytotoxic CD4+ and CD4+CD8dim+ T-cell clones infiltrating a cutaneous T-cell lymphoma. Blood 1998;91:4331-4342.

14. Desfrançois J, Moreau-Aubry A, Vignard V, Godet Y, Khammari A, Dréno B, Jotereau F, Gervois N. Double positive CD4CD8 $\alpha \beta$ T cells: A new tumorreactive population in human melanomas. PLoS One 2010;5:e8437.

15. Sarrabayrouse G, Corvaisier M, Ouisse LH, Bossard C, Mével B Le, Potiron L, Meurette G, Gervois N, Jotereau F. Tumor-reactive CD4+CD8 $\alpha \beta+C D 103+\alpha \beta T$ cells: A prevalent tumor-reactive T-cell subset in metastatic colorectal cancers. Int J Cancer 2011;128:2923-2932.

16. Parel $Y$, Aurrand-lions $M$, Scheja A, Dayer J, Roosnek E, Chizzolini C. Presence of CD4+ CD8+ double-positive T cells with very high interleukin-4 production potential in lesional skin of patients with systemic sclerosis. Arthritis Rheum 2007;56:3459-3467.

17. Das G, Augustine MM, Das J, Bottomly K, Ray P, Ray A. An important regulatory role for $\mathrm{CD} 4+\mathrm{CD} 8 \mathrm{~T}$ cells in the intestinal epithelial layer in the prevention of inflammatory bowel disease. Proc Natl Acad Sci 2003; 100:5324-5329.

18. Berrih S, Gaud C, Bach MA, Le Brigand H, Binet JP, Bach JF. Evaluation of T cell subsets in myasthenia gravis using anti-T cell monoclonal antibodies. Clin Exp Immunol 1981;45:1-8.

19. Quandt D, Rothe K, Scholz R, Baerwald CW, Wagner U. Peripheral CD4CD8 double positive $t$ cells with a distinct helper cytokine profile are increased in rheumatoid arthritis. PLoS One 2014;9:1-11.

20. Iwatani $Y$, Hidaka $Y$, Matsuzuka $F$, Kuma K, Amino N. Intrathyroidal lymphocyte subsets, including unusual CD4+ CD8+ cells and CD3loTCR alpha beta lo/-CD4-CD8- cells, in autoimmune thyroid disease. Clin Exp Immunol 1993;93:430-436.

21. Pérez $A R$, Morrot $A$, Berbert $L R$, Terra-Granado $E$, Savino W. Extrathymic CD4 ${ }^{+}{ }^{C D} 8+$ lymphocytes in Chagas disease : possible relationship with an immunoendocrine imbalance. Ann N Y Acad Sci 2012;1262:27-36.

22. Giraldo NA, Bolaños NI, Cuellar A, Guzman $F$, Uribe AM, Bedoya $A$, Olaya $N$ Cucunubá ZM, Roa N, Rosas F, Velasco V, Puerta CJ, González JM. Increased CD4+/CD8+ double-positive T cells in chronic chagasic patients. PLoS Negl Trop Dis 2011;5:e1294. 
23. Pérez-Antón E, Egui A, Thomas MC, Puerta CJ, González JM, Cuéllar A, Segovia M, López MC. Impact of benznidazole treatment on the functional response of Trypanosoma cruzi antigen-specific CD4 + CD8 + T cells in chronic Chagas disease patients. PLoS Negl Trop Dis 2018;12:e006480.

24. Rojas-Pandales F, Bolaños N, Mercado M, Gonzalez JM, Cuellar A, CifuentesRojas C. Valores de referencia de células asesinas naturales ( NK y NKT) en donantes de sangre de Bogotá. Acta Medica Colomb 2007;32:124-128.

25. Phan MT, Chun S, Kim SH, Ali AK, Lee SH, Kim S, Kim SH, Cho D. Natural killer cell subsets and receptor expression in peripheral blood mononuclear cells of a healthy Korean population: Reference range, influence of age and sex, and correlation between NK cell receptors and cytotoxicity. Hum Immunol 2017;78:103-112.

26. Miller JD, van der Most RG, Akondy RS, Glidewell JT, Albott $S$, Masopust D, Murali-Krishna K, Mahar PL, Edupuganti S, Lalor S, Germon S, Del Rio C, Mulligan MJ, Staprans SI, Altman JD, Feinberg MB, Ahmed R. Human effector and memory CD8+ T cell responses to smallpox and yellow fever vaccines. Immunity 2008;28:710-722.

27. Frentsch M, Arbach 0 , Kirchhoff D, Moewes B, Worm M, Rothe M, Scheffold A, Thiel A. Direct access to CD4+ T cells specific for defined antigens according to CD154 expression. Nat Med 2005;11:1118-1124.
28. Ripoll JG, Giraldo NA, Bolaños NI, Roa N, Rosas F, Cuéllar A, Puerta CJ, González JM. T cells responding to Trypanosoma cruzi detected by membrane TNF- $\alpha$ and CD154 in chagasic patients. Immun Inflamm Dis 2018;6:47-57.

29. Lai J, Luo S, Ho L. Targeting the CD40-CD154 signaling pathway for treatment of autoimmune arthritis. Cells 2019;8:1-18.

30. Topalian SL, Drake CG, Pardoll DM. Immune checkpoint blockade: a common denominator approach to cancer therapy. Cancer Cell 2015;27:450-461.

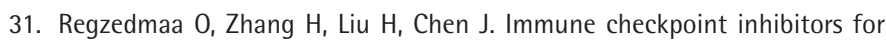
small cell lung cancer: opportunities and challenges. Onco Targets Ther 2019;12:4605-4620.

32. Planes-Laine G, Rochigneux P, Bertucci $F$, Chrétien A-S, Viens $P$, Sabatier $\mathrm{R}$, Gonçalves A. PD-1/PD-L1 targeting in breast cancer: the first clinical evidences are emerging. A literature review. Cancers (Basel) 2019;11. pii: E1033. 